\title{
Új szempontok a sószenzitív hypertoniák patomechanizmusában
}

\author{
Tulassay Tivadar egyetemi tanár, akadémikus \\ 70. születésnapjára
}

\author{
Sulyok Endre dr. \\ Pécsi Tudományegyetem, Egészségtudományi Kar, Egészségtudományi Doktori Iskola, Pécs
}

\begin{abstract}
Az összefoglaló közlemény áttekinti a hypertoniabetegség kialakulásának főbb stádiumait a rizikófaktoroktól az endotheldiszfunkción, a vascularis stiffnessen és a sclerotisatión keresztül a célszervkárosodások kialakulásáig. Bemutatja a sóbevitel patogenetikai szerepét, és elemzi azokat a renalis és extrarenalis mechanizmusokat, melyek szerepet játszhatnak a sószenzitív hypertonia kialakulásában. A korábban általánosan elfogadott elmélet, miszerint a vese elégtelen nátriumexkréciója és a következményes extracelluláris (EC) volumenexpanzió felelős a vérnyomás emelkedéséért, módosításra szorul, mivel disszociációt igazoltak egyrészt a retineált nátrium mennyisége és az EC volumene, másrészt a retineált nátrium és a vérnyomás között. Kimutatták, hogy a subcutan interstitium negatív töltéshordozó makromolekulái (glükózaminoglikánok, GAG-k) a nátriumionokat ozmotikusan inaktív formában reverzibilisen megkötik, a szöveti hypertonicitas monocyta/macrophag akkumulációhoz vezet, és ezen sejtek aktivációja a tonicity-responsive enhancer binding protein (TonEBP) expressziójához, ezen keresztül a vascularis endothelialis növekedési faktor $\mathrm{C}$ szekréciójához, valamint a lymphangiogenesis és a nitrogén-monoxid (NO)-termelés fokozódásához vezet. Az expandált lymphás rendszer az interstitium fölös nátrium- és folyadékkészleteit a keringésbe drenálja. A rendszer pufferfunkciójának beszúkülése hypertonia kialakulásához vagy súlyosbodásához vezet. Hasonló puffer- és barrierfunkciót tulajdonítanak a vascularis endothelium luminális felszínét borító glycocalyxnak is. Amennyiben az erek nátriumterhelése meghaladja a glycocalyx pufferkapacitását, az endothelsejtek felszínén a nátriumcsatornák expressziója és aktivitása fokozódik, a sejtek nátriumtartalma megnő, NO-termelésük csökken, a sejtek merevvé válnak következményesen fokozott vascularis rezisztenciával. Fontos felismerés, hogy a magas sóbevitel a vérnyomástól függetlenül is jelentős patogenetikai tényező a célszervkárosodás kialakulásában. A kóros történések hátterében a Th17-sejtek indukcióját és aktiválását, valamint számos proinflammatoricus és profibroticus citokin fokozott expresszióját mutatták ki.
\end{abstract}

Orv Hetil. 2019; 160(2): 43-49.

Kulcsszavak: nátrium, vérnyomás, renalis szabályozás, extrarenalis mechanizmus

\section{New aspects of the pathomechanism of salt-sensitive hypertension}

This article shortly outlines the evolution of hypertonia from risk factors to end-organ damage. The pathogenetic role of salt intake is underlined and in the light of recent clinical and experimental observations, the importance of renal and extrarenal mechanism in the development of salt-sensitive hypertension is analysed. The generally accepted concept that the inefficient renal sodium excretion and the subsequent expansion of the extracellular space is the major factor in blood pressure elevation is challenged. Evidences have been provided that the retained sodium dissociates from the volume of extracellular space and, also from the blood pressure. It has been shown that the negatively charged macromolecules in the subcutaneous interstitium bind sodium ions in osmotically inactive form and store sodium reversibly. The local tissue hypertonicity induces monocytes/macrophages invasion and activation that causes increased expression of tonicity-responsive enhancer binding protein (TonEBP) and the secretion of vascular endothelial growth factor $\mathrm{C}$ that result in enhanced lymphangiogenesis. The expanded lymphatic system drains the excess sodium and volume back to the circulation. The reduction of buffer function of this system may contribute to the development or to worsening of hypertension. Similar buffer and barrier functions are attributed to the glycocalyx that covers the luminal surface of vascular endothelium. It is also recognised that the high sodium intake alone is an important pathogenetic factor in end-organ damage independent of hypertension. This may be accounted for by the induction and activation of Thl7 cells as well as by the increased production of several pro-inflammatory and pro-fibrotic cytokines.

Keywords: sodium, blood pressure, renal regulation, extrarenal mechanism

Sulyok E. [New aspects of the pathomechanism of salt-sensitive hypertension]. Orv Hetil. 2019; 160(2): 43-49.

(Beérkezett: 2018. szeptember 17.; elfogadva: 2018. október 11.) 


\section{Rövidítések}

ADMA = aszimmetrikus dimetil-arginin; CCL/CXCL = kemokinligand; D25OHD = szérum-25-hidroxivitamin D; EC = extracelluláris; eNOS = endothelialis nitrogén-oxid-szintetáz; GAG = glükózaminoglikán; GAG-k = kötőszöveti glükózaminoglikán; $\mathrm{IL}=$ interleukin; $\mathrm{MCP}=$ (monocyte chemotactic protein) monocytakemotaktikus fehérje; MRC = mannózreceptor; $\mathrm{mRNS}=$ (messenger $)$ hírvivő ribonukleinsav; $\mathrm{NaCl}=$ nátriumklorid; NGAL $=$ (neutrophil gelatinase-associated lipocalin) neutrophil zselatináz asszociálta lipokalin; $\mathrm{NO}=$ nitrogén-monoxid; NOS = nitrogén-monoxid-szintáz; Sgk-1 = (serum and glycocorticoid-inducible kinase) szérum- és glükokortikoidindukálható kináz-1; TLR = (Toll-like receptor) Toll-szerü receptor; TonEBP = tonicity-responsive enhancer binding protein; TREM = triggering receptor expressed in myeloid cell; VEGF-C = (vascular endothelial growth factor $\mathrm{C}$ ) vascularis endothelialis növekedési faktor $\mathrm{C}$; VEGF- $\mathrm{R}=\mathrm{a}$ vascularis endothelialis növekedési faktor receptora

\section{A hypertoniabetegség evolúciója}

A magasvérnyomás-betegség és szövődményei súlyos népegészségügyi problémát jelentenek, amennyiben a cardiovascularis morbiditás és mortalitás hazánkban rendkívül magas, az összesített halálozási arány 45,9\%-át jelenti, ami kétszeresen meghaladja az európai uniós országok átlagértékét $[1,2]$.

A hypertoniabetegség kialakulása hosszú folyamat, mely egymással szorosan összefüggő, egymásra ható elemekból épül fel. A tradicionális vagy az újabban felismert rizikófaktorok először az endothel funkciójának kóros változásait, majd az érfal szerkezetének és kémiai összetételének módosulását váltják $\mathrm{ki}$, amit a sclerotisatio, majd a célszervkárosodások kialakulása követ (1. ábra).

A hagyományos rizikófaktorok mellett (obesitas, dyslipidaemia, diabetes mellitus, krónikus veseelégtelenség, dohányzás, magas sófogyasztás, inaktivitás, stresszállapotok) egyre inkább előtérbe kerülnek a nem hagyományos kockázati tényezők [3]. Ezek között is kiemelt jelentősé-

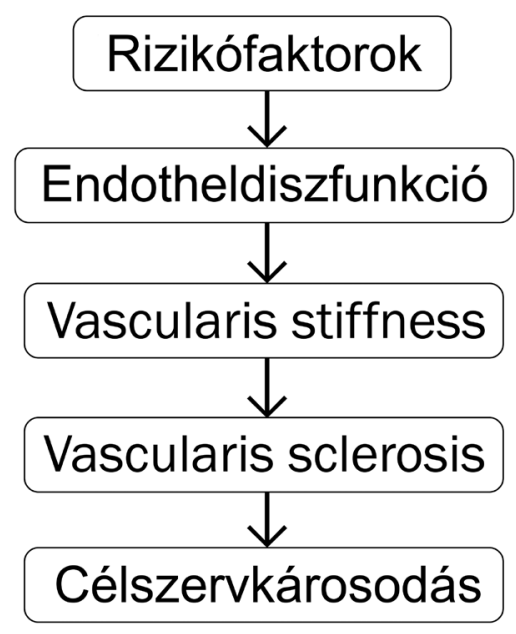

| A hypertoniabetegség evolúciója gú az alacsony intenzitású krónikus gyulladás, az agreszszív szabadgyök-képződés, a glikációs végtermékek és az újabban felismert $\mathrm{D}_{3}$-vitamin-hiány, az aszimmetrikus dimetil-arginin (ADMA) és az alacsony születési súly. Megjegyzendő, hogy a hagyományos rizikótényezők többsége az újabban felismert speciális rizikófaktorokon keresztül vagy azok részvételével fejtik ki kedvezőtlen hatásukat.

Általánosan elfogadott, hogy szoros negatív kapcsolat van a szérum-25-hidroxivitamin D (D25OHD) és a cardiovascularis megbetegedések gyakorisága között, és a $\mathrm{D}_{3}$-vitamin-szupplementáció protektív hatású. Felvetették ugyanakkor annak lehetőségét is, hogy a cardiovascularis kockázatot nem maga a $\mathrm{D}_{3}$-vitamin hiánya, hanem az aktív D-vitamin, a D-vitamin-kötő fehérje és a parathormon közötti interakció zavara okozza [4]. Még valószínúbb, hogy a kóros cardiovascularis történések hátterében a Klotho-FGF23 - aktív $\mathrm{D}_{3}$-vitamin - parathormonrendszer diszfunkciója áll [5]. Az ADMA a NOszintáz endogén inhibitora, mely fontos szerepet játszik a cardiovascularis betegségek kialakulásában és progreszsziójában. Mint mediátor és marker, plazmaszintjének emelkedése szoros összefüggést mutat a megbetegedés súlyosságával és a várható prognózissal [6]. Az alacsony születési súly és a felnőttkori betegségek közötti összefüggés feltárása $D$. Barker nevéhez füződik, aki kimutatta, hogy az alacsony születési súly, a magzat elégtelen méhen belüli tápláltsága fontos kockázati tényező a felnőtttkori cardiovascularis megbetegedések kialakulása szempontjából. A méhen belüli kedvezőtlen környezeti hatások (elégtelen táplálás, krónikus hypoxia, stressz) a fejlődés kritikus időszakában olyan adaptív reakciókat indukálnak, melyek rövid távon biztosítják a magzat túlélését, hosszú távon azonban az anyagcsere-, endokrin, renalis és vascularis homeostasist negatívan befolyásolják [7]. Nephrologiai szempontból fontos kiemelni, hogy az alacsony születési súly a nephronok számának csökkenésével jár, ami önmagában is hiperfiltrációhoz és ennek következtében hypertonia kialakulásához és progressziójához vezethet.

A rizikófaktorok tartós fennállása esetén a vasculopathia korai fázisaként endotheldiszfunkció alakul ki. Az endothelium múköódésenek általánosan elfogadott indikátora az L-arginin/NO rendszer funkcionális integritása, a megfelelő NO-termelés és az ezt jelző endotheliumdependens, áramlásfüggó vasodilatatio.

A rendszer alapvetô elemei az endothelialis sejtek kationos aminosavtranszporterének expressziója, a sejtek Larginin-felvétele, a NO-szintáz, valamint a képződő NO hatásának közvetítésében részt vevő szolúbilis guanilátcikláz megfelelő expressziója és aktivitása. A NOS aktivitásának meghatározásában döntő jelentősége van az ADMA-nak, melynek koncentrációját képződésének (metilált fehérjék proteolízise) és eliminációjának (dimetil-arginin dimetil-aminohidroláz) üteme határozza meg [8]. 
Az endotheldiszfunkció progressziója az érfal átépüléséhez, rugalmasságának csökkenéséhez, „pascularis stiffness” kialakulásához vezet. A folyamat fontos tényezője a vascularis simaizomsejtek proliferációja, a kollagéndepozíció és az elasztinfragmentáció. A klinikumban széles körben elterjedt gyakorlat szerint a vascularis status jellemzésére kitúnően alkalmas az augmentációs indexnek és a pulzushullám terjedési sebességének a meghatározása.

Nagyszámú prospektív és keresztmetszeti vizsgálat igazolta, hogy a vascularis stiffness érzékeny markere és megbízható előrejelzője a cardiovascularis történéseknek, és a patomechanizmus teljesebb megértésével terápiás célpontként is szolgál.

A vascularis stiffness és a vasculopathia kialakulásában meghatározó tényező a vascularis calcificatio, mely aktív, sejt közvetítette folyamat. Patogenezisében az alábbi elemeknek tulajdonítanak kiemelt jelentőséget: a) a vascularis simaizomsejtek osteoblast/chondrocyta-szerü sejtekké történő transzformációja, b) a sejtek fokozott kalcium- és foszfátfelvétele, c) a simaizomsejtek apoptózisa és microvesiculumkibocsátása és d) a keringő vagy lokálisan képződő inhibitorok relatív vagy abszolút hiánya [9]. Újabb vizsgálatok felvetették a csontanyagcsere kóros változásai és az arteriosclerosis közötti kapcsolatot is, amennyiben a) az osteodensitas csökkenése növeli az arteriosclerosis és a cardiovascularis események kockázatát, b) azok a molekuláris mechanizmusok, melyek a csontképzésért felelősek, megtalálhatók lokálisan a vascularis laesiókban is, és c) a két patológiás folyamat kialakulásában azonos rizikótényezők lehetnek jelen [10].

A hypertoniabetegség fejlődésének hosszú folyamatában a végső fázist a célszervkárosodások megjelenése jelenti. A vascularis változások mellett vagy azokon túl szerv/szövet specifikus történések zajlanak, melyek lényeges eleme az epithelialis-mesenchymalis transitio, az aktivált fibroblastok fokozott növekedésifaktor- és proinflammatoricuscitokin-expressziója, az extracelluláris mátrix expanziója és a szöveti fibrosis. A komplex folyamatok iniciálásában és fenntartásában a vérnyomástól függetlenül is fontos patogenetikai tényező a szöveti hypoxia, az alacsony intenzitású krónikus gyulladás, az agresszív szabadgyök-képződés és az endotheldiszfunkció $[11]$.

A hypertoniabetegség kialakulásának és progressziójának bemutatása, egyes fázisainak önálló elemzése logikusnak és didaktikai szempontból indokoltnak túnik. Hangsúlyozni kell azonban, hogy az egyes fejlődési szakaszok nem különíthetők el élesen egymástól, nem feltétlenül épülnek egymásra, és a rizikófaktorok hypertonia nélkül közvetlenül is célszervkárosodást okozhatnak (például magas sófogyasztás).

\section{Sószenzitív, volumendependens hypertonia}

Epidemiológiai, klinikai, genetikai és állatkísérletes vizsgálatok igazolták, hogy a sóbevitel a vérnyomás-szabályozás fontos tényezője [12]. Ezt bizonyítandó szoros pozitív korreláció mutatható ki a vérnyomás és a napi sóbevitel között [13]. A diétás sómegszorítás csökkenteni képes a vérnyomást nemcsak hypertoniás, de normotoniás egyénekben is $[14,15]$.

A sószenzitivitás prevalenciáját hypertoniás betegekben 51\%-ra, míg normotensiós egyénekben 26\%-ra becsülik. Mivel a sószenzitivitás a cardiovascularis betegségek és mortalitás független rizikótényezője, a normotensiós sószenzitív felnőttek kumulatív mortalitása eléri a hypertoniás betegek értékét. Ezzel szemben a sórezisztens felnőtt egyének túlélési mutatói kedvezőbbek [15, 16].

Általános vélemény szerint szoros lineáris kapcsolat van a sóbevitel, a cardiovascularis események és a mortalitás között. Ugyanakkor meggyőző adatok arra hívják fel a figyelmet, hogy az optimális sóbevitel 3-6 g/nap közötti tartományban található, és ennél alacsonyabb értéknél is növekszik a kedvezőtlen cardiovascularis események kockázata, vagyis az összefüggés J-formával írható le. A jelenség hátterében részben a renin-angiotenzinaldoszteron rendszer fokozott aktivitása [17], részben pedig a sóbevitel vérnyomástól független cardiovascularis hatása tételezhető fel [18].

\section{Renalis mechanizmus}

A sószenzitív volumendependens hypertonia kialakulásában döntő jelentőséget tulajdonítanak a vese elégtelen nátriumürítő képességének. Hátterében komplex patológiai történések állnak, melyek fontos elemeit részben genetikai, részben környezeti tényezők határozzák meg. Ezek között kiemelendő a natriureticus faktorok csökkent aktivitása (atrialis natriureticus peptid, renalis dopaminerg, kallikrein-bradikinin, L-arginin-NO rendszerek) és a nátriumretineáló faktorok elégtelen szupprimálása vagy fokozott aktiválása (renin-angiotenzin-aldoszteron rendszer, renalis sympathoadrenalis rendszer). Ezeken túlmenően igazolták a renalis Na-reabszorpciót mediáló transzporterek, ioncsatornák up-regulációját is [19].

Demográfiai vizsgálatok szerint az afroamerikai etnikumhoz tartozók, az idős egyének és a postmenopausában lévő nők a sószenzitivitás kialakulása szempontjából különösen veszélyeztetettek [20, 21]. Fontos felismerés, hogy a káliumban, kalciumban, D-vitaminban, antioxidáns vitaminokban és L-argininben gazdag diéta csökkenti, míg a nyugati típusú diéta (telített zsírok, magas szacharóz és fruktóz) növeli a sószenzitív hypertonia és szövődményeinek kialakulását [22].

Számos humán és állatkísérletes megfigyelés alapján kérdésessé vált az a koncepció, hogy a vese beszúkült sóürítő képessége az egyedüli vagy legfontosabb patogenetikai tényező a sószenzitív hypertonia kialakulásában. A sóterhelés hatásának összehasonlító elemzésekor ugyanis azt figyelték meg, hogy az egészséges sórezisztens egyénekben a retineált nátrium, a vérvolumen és a percvolumen nagyobb mértékű növekedése ellenére a vérnyomás kevésbé változik, mint a sószenzitív hypertoniás bete- 
gekben. A nátriumretenció és a vérnyomás nyilvánvaló disszociációját a perifériás vascularis rezisztencia eltérő mértékű csökkenésével lehetett magyarázni, és felvetették volumentől független tényezők etiológiai szerepét [23].

\section{Extrarenalis szabályozás}

\section{Subcutan interstitium}

Heer és mtsai szerint a Na-retencióval járó magas sófogyasztás nem okoz extracelluláristér-expanziót [24], és sószenzitív patkánytörzsekben a hypertonia volumenexpanzió nélkül is létrejön [25].

A jelenség hátterének feltárására Titze és mtsai kidolgozták a Na-homeostasis szöveti szabályozásának koncepcióját. Megállapították, hogy sóterhelés esetén a $\mathrm{Na}$ részben ozmotikusan inaktív formában (kötötten) tárolódik, ezért a Na-retenció nem jár feltétlenül az extracelluláris tér expanziójával, bekövetkezhet a Na- és volumenhomeostasis disszociációja. Az ozmotikusan aktívinaktív $\mathrm{Na}$ reverzibilis átalakulása pufferként szolgál a volumen és vérnyomás megőrzése szempontjából [26]. A legjelentősebb inaktív Na-rezervoárt a csont- és porcszövet mellett a subcutan interstitium képezi. Az ozmotikusan inaktív Na-tárolás biokémiai alapját a kötőszöveti glükózaminoglikánok (GAG-k) képezik. A polianion természetű makromolekulák Na-akkumulációját a GAGok mennyisége, polimerizációja és töltéseik denzitása határozza meg [27]. A fentiek figyelembevételével leírták az interstitium - mint önálló folyadéktér - volumenének és Na-tartalmának sajátos, a volumenreguláció általánosan ismert formájától független szabályozását.

A szabályozás lényeges elemei: az interstitium GAGjaihoz kötötten ozmotikusan inaktív formában $\mathrm{Na}$ akkumulálódik, ami a makromolekulák közvetlen környezetében hypertonicitast generál. A szöveti tonicitas növekedése a mononukleáris phagocyták invázióját indukálja, és aktíválja ezen sejtek „tonicity-responsive enhancer binding protein" (TonEBP-) expresszióját, ami az interstitiumot infiltráló macrophagokban VEGF-Cszekréciót eredményez. A VEGF-C a VEGF-3R-on keresztül fokozza a lymphangiogenesist, növeli a nyirokrendszer teljesítményét, és a lymphaticus rendszer az interstitium szabaddá váló folyadék- - és Na- - készleteit a keringő plazmába drenálja.

A VEGF-C további hatása, hogy a VEGF-1- és -2-receptorokon keresztül növeli az eNOS expresszióját és aktiválását, ami a vascularis rezisztencia és a vérnyomás csökkenéséhez vezet [28].

A puffermechanizmus múködését állatkísérletes és klinikai megfigyelések egyaránt igazolják. A sószenzitív hypertonia állatmodelljében (Dahl patkánytörzs) az interstitium ozmotikusan inaktív Na-tároló kapacitása lényegesen elmarad a kontrollok értékétől, és ezekben az állatokban a sóterhelés volumenretenciót és hypertoniát okoz [26]. A mononukleáris phagocytasejtek TonEBP- deletiója a VEGF-C mRNS- és fehérjeexpressziójának csökkenését, a lymphaticus kapillárishálózat redukcióját, az interstitialis kloridclearance beszúküulését és sószenzitív hypertonia kialakulását okozza [29].

Hasonló mechanizmust feltételez, hogy mind krónikus vesebetegekben, mind egészséges egyénekben a sóbevitel manipulálásával azonos irányú változásokat lehet kiváltani a VEGF-C-szintekben [30]. További fontos bizonyíték, hogy a VEGF-C jelátviteli út megszakítása (szunitinib, lucitanib) onkológiai betegekben hypertoniát okoz [31]. A jelenséget állatkísérletes modellben is megfigyelték, amennyiben a VEGF-C-gátló kezelés (szunitinib) sószenzitív hypertoniát, a bőr NaCl-tartalmának növekedését és a lymphangiogenesis mérsékelt csökkenését váltotta ki [32]. A subcutan interstitium volumen/Na puffer múködésében a mononukleáris phagocyta kitüntetett szerepét elsőként Machnik és mtsai meggyőző vizsgálatai mutatták be [33].

\section{Endothelialis glycocalyx}

Újabb állatkísérletes és klinikai vizsgálatok igazolták, hogy a vascularis endothelium luminális felszínét borító glycocalyx ugyancsak fontos tényező a nátriumháztartás szabályozásában. A glycocalyx, melynek fö összetevői glikoproteinek, proteoglikánok és GAG-ok, dinamikus kapcsolatban áll a keringő plazmával, volumenét és öszszetételét az endothelsejtek a lokális mikrokörnyezet változásaitól függően szabályozzák. Szerepe van a vascularis permeabilitás és homeostasis fenntartásában, antiinflammatoricus és antiatherogen tulajdonságokkal rendelkezik, és fontos mediátora az áramlásfüggő NO-szintézisnek. Kiemelt jelentőséget tulajdonítanak annak is, hogy a GAG komponens negatív töltéshordozói révén képes megkötni és reverzibilisen tárolni a nátriumionokat, ily módon első vonalbeli nátriumpufferként szerepel, és nagyban hozzájárul a volumenháztartás egyensúlyának megőrzéséhez [34].

In vitro végzett humán vizsgálatok szerint $\sim 30 \mathrm{mmol}$ nátrium inaktiválására képes, in vivo megfigyelések alapján azonban ennél 7-30-szor nagyobb nátriumkötő képességgel rendelkezik [35].

Amennyiben az endothelialis glycocalyx volumene csökken, vagy integritása sérül, nátriumkötő képessége és pufferfunkciója beszúkül, a sószenzitív hypertonia kialakulásának kockázata megnő. A klinikumban ilyen állapotok a hypercholesterinaemia, a diabetes mellitus, az érsebészeti beavatkozások, a szepszis, a krónikus vesebetegségek, a dialíziskezelés, valamint az akut és krónikus hyperglykaemia [34]. A klinikai gyakorlatban a glycocalyx lebontásának elfogadott markere a szindekán-1 plazmaszintjének emelkedése [36]. Fontos felismerés, hogy akut nátrium- és/vagy volumenterhelés ugyancsak csökkenti a glycocalyx volumenét [37], bár lehetséges, hogy az a csökkenés a glycocalyx mennyiségi változása mellett denzitásának növekedését is tükrözi. 
blood

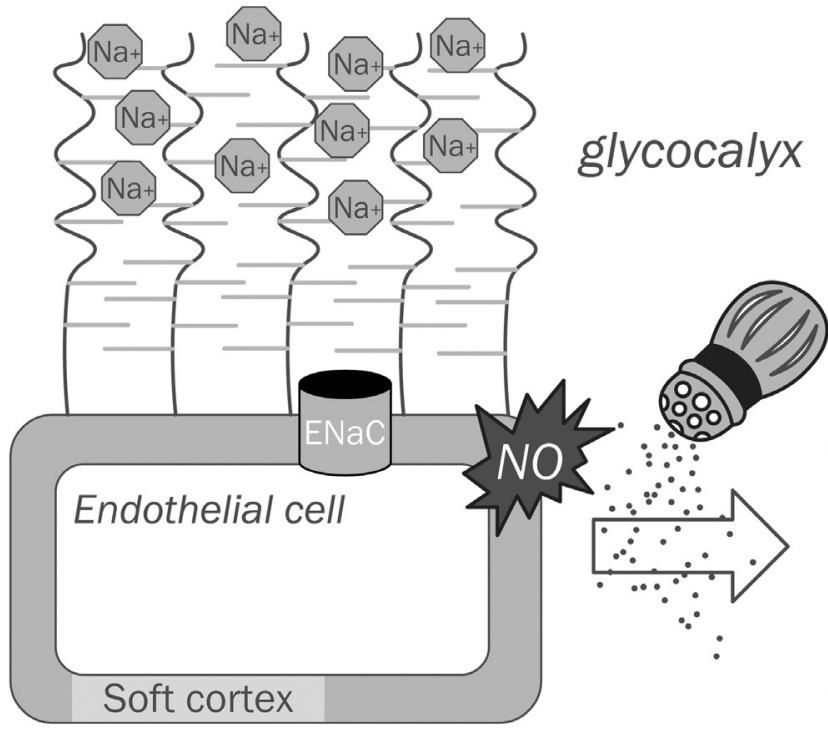

interstitium

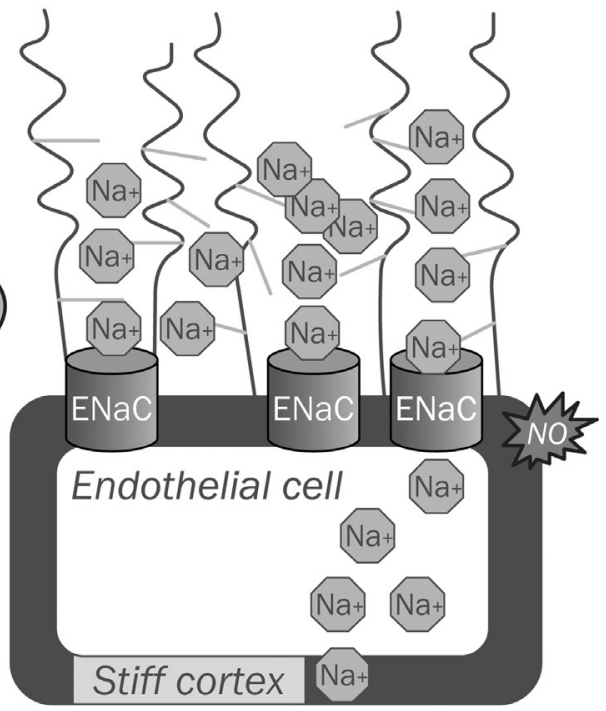

Nat

\begin{tabular}{l|l} 
2. ábra & $\begin{array}{l}\text { A glycocalyx szerepe a Na szabályozásában } \\
\text { Copyright transfer: a 2. ábra közléséhez a kiadó engedélyével rendelkezünk. Az eredeti megjelenés adatai: Kusche-Vihrog K, Jeggle P, Oberleithner } \\
\text { H. The role of ENaC in vascular endothelium. Pflugers Arch. 2014; 466(5): 855. Fig. 1. }\end{array}$
\end{tabular}

A glycocalyx pufferfunkciója mellett kiemelt jelentőségú, hogy nátriumbarrierként védi az endothelsejteket a nátrium beáramlásától és annak negatív következményétől. Nátriumterhelés hatására ezen barrierfunkciója csökken, az endothelsejtek luminális felszínén található nátriumcsatornák denzitása/aktivitása és a sejtek nátriumfelvétele megnő, ennek következtében a sejtek merevvé válnak, NO-termelésük mérséklődik, és fokozódik az értónus [38] (2. ábra).

Újabb vizsgálatok szerint az endothelialis glycocalyx mint mechanotranszduktor is meghatározó tényező az áramlásfüggő NO-termelés szabályozásában. A glycocalyx-lipid bilayer-cytoskeleton rendszer feszülése mechanoszenzitív ioncsatornákat aktivál, növeli a kalciumionok beáramlását, a NO-termelés fokozódását, és vasorelaxatiót okoz [39]. A GAG-ok enzimatikus eliminálása a glycocalyx protektív funkciójának beszúkülését, míg a heparán-szulfát/dermatán-szulfát (szulodexid) szupplementációja a vascularis protekció helyreállítását eredményezi, és csökkenti a sószenzitív hypertonia kialakulásának veszélyét $[40,41]$.

\section{Sóbevitel és célszervkárosodás}

Meggyőző vizsgálatok igazolják, hogy a magas sóbevitel a glycocalyx-endothelium integritásának megbontásán, az endotheldiszfunkció és a hypertonia kialakításán túl is fontos patogenetikai tényező a célszervkárosodások kialakulásában. A magas sóbevitel következtében immunológiai folyamatok aktiválódnak, és az autoimmun beteg- ségek progressziója következik be. A kóros történések hátterében a Th17-sejtek indukcióját és aktiválását mutatták ki [42].

Zhang és mtsai szerint a magas NaCl-koncentráció megváltoztatja a macrophagok génexpressziós profilját, amennyiben a proinflammatoricus kemokinligandok (CCL2, CCL8, CXCLl/2), citokinek (ILß1, IL8) és Toll-szerü receptorok (TLR3, TLR4) expresszióját fokozza, az antiinflammatoricus molekulák expressziójára pedig gátló hatással bír (CCL18, CCL22, TREM2, MRCl) [43].

Humán vizsgálatok is igazolták, hogy magas sóbevitel esetén a keringő monocyták száma és a gyulladásos citokinek (IL6, IL23) szintje emelkedik, míg az antiinflammatoricus citokinek (IL10) szintje mérséklődik. Különösen jelentős az IL23 indukciója, mivel ez a citokin tartósan fokozza a naiv T-sejtek Th17-sejtekké történő polarizációját $[44,45]$.

A magas sóbevitel és a szöveti károsodás közötti kapcsolatot ismételten bizonyították. Pletinck és mtsai szerint a sóterhelés a gyulladásos citokinek up-regulációja mellett epithelialis-mesenchymalis átalakulást indukál, ami peritonealis fibrosishoz és a submesothelialis réteg megvastagodásához vezet [46]. A sóbevitel vesekárosító hatását mutatja, hogy subtotalis nephrectomiát követően a NaCl-terhelés hatására a szöveti macrophaginfiltráció fokozódott, fibrosis alakult ki, és megnőtt az interleukin-6, a monocytakemotaktikus protein-1 (MCP), a szérum- és glükokortikoidindukálható kináz-l (Sgkl) és a TonEBp mRNS-einek szöveti expressziója. Az MCPl 
receptorának hiányában (kemokinreceptor-2, CCR2) a szövetek macrophaginfiltrációja és szekunder fibrosisa nem következett be [47]. A komplex folyamat központi eleme a nátriumfüggő, macrophagspecifikus kemotaxis és a TonEBP-szekréció fokozódása. Kiemelendő, hogy a szöveti macrophaginfiltrációt kiváltó ozmotikus stressz NaCl-specifikus; sem az urea-, sem a mannitolakkumuláció nem bír ilyen hatással.

Fontos megjegyezni, hogy a sóterhelés hatására bekövetkező hisztopatológiai változások nemcsak hypertoniás, hanem normotoniás modellekben is észlelhetők. Tartósan magas sóbevitel Wistar Kyoto patkánytörzsben a vérnyomás emelése nélkül renalis proximalis tubulusdilatatiót és -degenerációt, valamint tubulointerstitialis fibrosist okozott. A morfológiai változásokat a korai tubuluslaesiót jelző markerek(neutrophil gelatinase-associated lipocalin; NGAL és vanin-1; pantetheinase), a vizelet koncentrációjának szignifikáns emelkedése kíséri. Patofiziológiai szempontból különösen jelentős a vanin-1 emelkedése, mivel ez az enzim a ciszteamin képződését katalizálja, ami az antioxidáns enzimek aktivitását csökkentve hozzájárul a szövetek szabadgyök-károsodásához [48].

A NaCl direkt szöveti hatását a cardiovascularis rendszerben is kimutatták. A magas sóbevitel a cardialis macrophag-TonEBP/VEGF-C jelátviteli utat is aktiválta. Ennek következtében a bal kamrai interstitiumban és perivascularis térben nagyfokú macrophaginfiltráció és fibrosis alakul ki, fokozott lymphangiogenesissel, a bal kamra volumenének jelentős növekedésével, funkciójának beszúlkülésével és a hypertonia súlyosbodásával [49]. Nagy esetszámú, echokardiográfos humán vizsgálatok is igazolták, hogy a napi 3,7 g-ot meghaladó nátriumbevitel a szívizomzat átépüléséhez, hypertrophiájához és mind a systolés, mind a diastolés funkció beszúküléséhez vezet $[50]$.

Anyagi támogatás: A szerző anyagi támogatásban nem részesült.

A szerző a cikk végleges változatát elolvasta és jóváhagyta.

Érdekeltségek: A szerzőnek nincsenek érdekeltségei.

\section{Irodalom}

[1] WHO Regional Office for Europe. European health for all database 2009 (HFA-DB). Available from: http://data.euro.who. int [accessed: January 20, 2010].

[2] Nagy B, Nagy-Lórincz Zs, Bakacs M, et al. Hungarian Diet and Nutritional Status Survey - OTÁP2014. III. Macroelement intake of the Hungarian population. [Országos Táplálkozás és Tápláltsági Állapot Vizsgálat - OTÁP2014. III. A magyar lakosság makroelem-bevitele.] Orv Hetil. 2017; 158: 653-661. [Hungarian]

[3] Barna I, Nyúl D, Szentes T, et al. Review of the relation between gut microbiome, metabolic disease and hypertension. [A bélmik- robiom, a metabolikus betegségek és a hypertonia kapcsolatának irodalmi áttekintése.] Orv Hetil. 2018; 159: 346-351. [Hungarian]

[4] Qi L, Ma W, Heianza Y, et al. Independent and synergistic associations of biomarkers of vitamin D status with risk of coronary heart disease. Arterioscler Thromb Vasc Biol. 2017; 37: 22042212 .

[5] Kuro-o M. Phosphate and Klotho. Kidney Int Suppl. 2011; 79(S121): S20-S23.

[6] Böger RH, Sullivan LM, Schwedhelm E, et al. Plasma asymmetric dimethylarginine and incidence of cardiovascular disease and death in the community. Circulation 2009; 119: 1592-1600.

[7] Barker DJ, Osmond C. Infant mortality, childhood nutrition, and ischaemic heart disease in England and Wales. Lancet 1986; 1(8489): 1077-1081.

[8] Moncada S, Higgs A. The L-arginine-nitric oxide pathway. N Engl J Med. 1993; 329: 2002-2012.

[9] Shroff RC, Shanahan CM. The vascular biology of calcification. Semin Dial. 2007; 20: 103-109.

[10] Vassalle C, Mazzone A. Bone loss and vascular calcification: a bidirectional interplay? Vascul Pharmacol. 2016; 86: 77-86.

[11] Brenner D, Labreuche J, Touboul PJ, et al. Cytokine polymorphisms associated with carotid intima-media thickness in stroke patients. Stroke 2006; 37: 1691-1696.

[12] Frohlich ED. The salt conundrum: a hypothesis. Hypertension 2007; 50: 161-166.

[13] Meneton P, Jeunemaitre X, de Wardener HE, et al. Links between dietary salt intake, renal salt handling, blood pressure, and cardiovascular diseases. Physiol Rev. 2005; 85: 679-715.

[14] Adrogué HJ, Madias NE. Sodium and potassium in the pathogenesis of hypertension. N Engl J Med. 2007; 356: 1966-1978.

[15] Cook NR, Cutler JA, Obarzanek E, et al. Long term effects of dietary sodium reduction on cardiovascular disease outcomes: observational follow-up of the trials of hypertension prevention (TOHP). BMJ 2007; 334: 885-888.

[16] Barba G, Galletti F, Cappuccio FP, et al. Incidence of hypertension in individuals with different blood pressure salt-sensitivity: results of a 15-year follow-up study. J Hypertens. 2007; 25: $1465-1471$.

[17] Weinberger MH, Fineberg NS, Fineberg SE, et al. Salt sensitivity, pulse pressure, and death in normal and hypertensive humans. Hypertension 2001; 37: 429-432.

[18] Graudal NA, Hubeck-Graudal T, Jurgens G. Effects of low sodium diet versus high sodium diet on blood pressure, renin, aldosterone, catecholamines, cholesterol, and triglyceride. Cochrane Database Syst Rev. 2011; 11: CD004022.

[19] O'Donnell M, Mente A, Rangarajan S, et al. Urinary sodium and potassium excretion, mortality, and cardiovascular events. N Engl J Med. 2014; 371: 612-623.

[20] Pilic L, Pedlar CR, Mavrommatis Y. Salt-sensitive hypertension: mechanisms and effects of dietary and other lifestyle factors. Nutr Rev. 2016; 74: 645-658

[21] He J, Gu D, Chen J, et al. Gender difference in blood pressure responses to dietary sodium intervention in the GenSalt study. J Hypertens. 2009; 27: 48-54.

[22] Richardson SI, Freedman BI, Ellison DH, et al. Salt sensitivity: a review with a focus on non-Hispanic blacks and Hispanics. J Am Soc Hypertens. 2013; 7: 170-179.

[23] Kurtz TW, DiCarlo SE, Pravenec M, et al. An alternative hypothesis to the widely held view that renal excretion of sodium accounts for resistance to salt-induced hypertension. Kidney Int. 2016; 90: 965-973.

[24] Heer M, Baisch F, Kropp J, et al. High dietary sodium chloride consumption may not induce body fluid retention in humans. Am J Physiol Renal Physiol. 2000; 278: F585-F595.

[25] Qi N, Rapp JP, Brand PH, et al. Body fluid expansion is not essential for salt-induced hypertension in SS/Jr rats. Am J Physiol. 1999; 277: Rl392-R1400. 
[26] Titze J, Krause H, Hecht H, et al. Reduced osmotically inactive $\mathrm{Na}$ storage capacity and hypertension in the Dahl model. Am J Physiol Renal Physiol. 2002; 283: Fl34-F141.

[27] Titze J, Shakibaei M, Schafflhuber M, et al. Glycosaminoglycan polymerization may enable osmotically inactive $\mathrm{Na}^{+}$storage in the skin. Am J Physiol Heart Circ Physiol. 2004; 287: H203-H 208.

[28] Machnik A, Neuhofer W, Jantsch J, et al. Macrophages regulate salt-dependent volume and blood pressure by a vascular endothelial growth factor-C-dependent buffering mechanism. Nat Med. 2009; 15: 545-552.

[29] Wiig H, Schröder A, Neuhofer W, et al. Immune cells control skin lymphatic electrolyte homeostasis and blood pressure. J Clin Invest. 2013; 123: 2803-2815.

[30] Slagman MC, Kwakernaak AJ, Yazdani S, et al. Vascular endothelial growth factor $\mathrm{C}$ levels are modulated by dietary salt intake in proteinuric chronic kidney disease patients and in healthy subjects. Nephrol Dial Transplant. 2012; 27: 978-982.

[31] Soria JC, DeBraud F, Bahleda R, et al. Phase I/IIa study evaluating the safety, efficacy, pharmacokinetics, and pharmacodynamics of lucitanib in advanced solid tumors. Ann Oncol. 2014; 25: 2244-2251

[32] Lankhorst S, Severs D, Markó L, et al. Salt sensitivity of angiogenesis inhibition-induced blood pressure rise: role of interstitial sodium accumulation? Hypertension 2017; 69: 919-926.

[33] Machnik A, Dahlmann A, Kopp C, et al. Mononuclear phagocyte system depletion blocks interstitial tonicity-responsive enhancer binding protein/vascular endothelial growth factor $\mathrm{C}$ expression and induces salt-sensitive hypertension in rats. Hypertension 2010; 55: 755-761.

[34] Olde Engberink RH, Rorije NM, Homan van der Heide JJ, et al. Role of the vascular wall in sodium homeostasis and salt sensitivity. J Am Soc Nephrol. 2015; 26: 777-783.

[35] Potter DR, Jiang J, Damiano ER. The recovery time course of the endothelial cell glycocalyx in vivo and its implications in vitro. Circ Res. 2009; 104: 1318-1325.

[36] Vlahu CA, Vogt L, Struijk DG, et al. The endothelial glycocalyx and $\mathrm{Na}(+)$ and fluid overload in hemodialysis patients. Nephrol Dial Transplant. 2013; 28: i40-i41.

[37] Oberleithner H, Peters W, Kusche-Vihrog K, et al. Salt overload damages the glycocalyx sodium barrier of vascular endothelium. Pflugers Arch. 2011; 462: 519-528.

[38] Kusche-Vihrog K, Jeggle P, Oberleithner H. The role of ENaC in vascular endothelium. Pflugers Arch. 2014; 466: 851-859.

[39] Dragovich MA, Chester D, Fu BM, et al. Mechanotransduction of the endothelial glycocalyx mediates nitric oxide production through activation of TRP channels. Am J Physiol Cell Physiol. 2016; 311: C846-C853.

[40] Nader HB, Buonassisi V, Colburn P, et al. Heparin stimulates the synthesis and modifies the sulfation pattern of heparan sulfate proteoglycan from endothelial cells. J Cell Physiol. 1989; 140: 305-310.

[41] Broekhuizen LN, Lemkes BA, Mooij HL, et al. Effect of sulodexide on endothelial glycocalyx and vascular permeability in patients with type 2 diabetes mellitus. Diabetologia 2010; 53: 2646-2655.

[42] Kleinewietfeld M, Manzel A, Titze J, et al. Sodium chloride drives autoimmune disease by the induction of pathogenic THI7 cells. Nature 2013; 496: 518-522.

[43] Zhang WC, Zheng XJ, Du LJ, et al. High salt primes a specific activation state of macrophages, $\mathrm{M}(\mathrm{Na})$. Cell Res. 2015; 25 : 893-910.

[44] Yi B, Titze J, Rykova M, et al. Effects of dietary salt levels on monocytic cells and immune responses in healthy human subjects: a longitudinal study. Transl Res. 2015; 166: 103-110.

[45] Iwakura $Y$, Ishigame H. The IL-23/IL-17 axis in inflammation. J Clin Invest. 2006; 116: 1218-1222.

[46] Pletinck A, Consoli C, Van Landschoot M, et al. Salt intake induces epithelial-to-mesenchymal transition of the peritoneal membrane in rats. Nephrol Dial Transplant. 2010; 25: 16881696.

[47] Sakata F, Ito Y, Mizuno M, et al. Sodium chloride promotes tissue inflammation via osmotic stimuli in subtotal-nephrectomized mice. Lab Invest. 2017; 97: 432-446.

[48] Washino S, Hosohata K, Jin D, et al. Early urinary biomarkers of renal tubular damage by a high-salt intake independent of blood pressure in normotensive rats. Clin Exp Pharmacol Physiol. 2018; 45: 261-268.

[49] Yang GH, Zhou X, Ji WJ, et al. VEGF-C-mediated cardiac lymphangiogenesis in high salt intake accelerated progression of left ventricular remodeling in spontaneously hypertensive rats. Clin Exp Hypertens. 2017; 39: 740-747.

[50] Selvaraj S, Djousse L, Aguilar FG, et al. Association of estimated sodium intake with adverse cardiac structure and function: from the HyperGEN Study. J Am Coll Cardiol. 2017; 70: 715-724.

(Sulyok Endre dr., Pécs, Vörösmarty u. 4., 7621 e-mail: esulyok@t-online.hu)

\title{
Felhívás előfizetésre
}

\author{
Legyen Olvasónk a következő évben is! \\ Fizessen elő az Orvosi Hetilap 2019-es évfolyamára! \\ Egy füzet ára: $1150 \mathrm{Ft}$. \\ Éves előfizetési díj: $49900 \mathrm{Ft}$, nyugdijasoknak: $39990 \mathrm{Ft}$. \\ Az online változat éves előfizetési dija: $29990 \mathrm{Ft}$.
}

A cikk a Creative Commons Attribution 4.0 International License (https://creativecommons.org/licenses/by/4.0/) feltételei szerint publikált Open Access közlemény, melynek szellemében a cikk bármilyen médiumban szabadon felhasználható, megosztható és újraközölhető, feltéve, hogy az eredeti szerző és a közlés helye, illetve a CC License linkje és az esetlegesen végrehajtott módosítások feltüntetésre kerülnek. (SID_1) 